\title{
(TTTA)n polymorphism of CYP19 (aromatase gene) in Euro- and Afro-Brazilians
}

\author{
Kátia Kvitko, Janice Corrêa de Barros Nunes and Mara Helena Hutz \\ Instituto de Biociências, Universidade Federal do Rio Grande do Sul, Departamento de Genética, \\ Porto Alegre, RS, Brazil.
}

\begin{abstract}
We investigated the polymorphic tetranucleotide repeat (TTTA) ${ }_{n}$ located in the fourth intron of the CYP19 gene in two Brazilian populations. The frequencies of the five common alleles $(A)$ in Euro- and Afro-Brazilians were, respectively: seven repeats $(A 5), 0.586$ and 0.80 ; eight repeats $(A 4), 0.092$ and 0.06 ; nine repeats $(A 3), 0.014$ and 0.01 ; eleven repeats $(A 2), 0.284$ and 0.09 ; twelve repeats $(A 1), 0.021$ and 0.04 . In addition, one Euro-Brazilian individual had a rare allele with 13 repeats. The allelic frequencies in Euro- and Afro-Brazilians differed statistically $\left(p<10^{-3}\right)$. The two samples were found to be in Hardy-Weinberg equilibrium ( $p=0,828$ and $p=0,995)$.
\end{abstract}

Key words: CYP19, gene polymorphism.

Received: February 24, 2003; Accepted: March 26, 2004.

The CYP19 gene encodes an aromatase protein, which has a role in the conversion of $\mathrm{C} 19$ androgenic steroids into estrogens. A polymorphic tetranucleotide repeat (TTTA $)_{n}$ is located in the fourth intron of CYP19, some alleles apparently determining a higher susceptibility to breast cancer (Kristensen et al., 1998, 2000). A few studies have demonstrated ethnic differences related to this polymorphism (Probst-Hensch et al., 1999; Gu et al., 2001).

The aim of the present study was to investigate if this polymorphism differed between Euro-derived and Afroderived Brazilian populations.

The European-derived sample consisted of 146 unrelated healthy individuals referred for paternity testing. The 124 Afro-Brazilians were ascertained at the central laboratory of a general public hospital to which they went for routine blood examination. The University Ethical Committee approved the investigation.

Genomic DNA was extracted from total blood by a salting out method (Miller et al., 1988). The region encompassing the fourth intron of CYP19 was amplified by the polymerase chain reaction (PCR), primers and the temperature profile of each cycle being as previously described (Kristensen et al., 1998). Genotype patterns were determined after $10.5 \%$ polyacrilamide gel electrophoresis and ethidium bromide staining. Allelic frequencies were estimated by gene counting. Agreement of genotypic frequencies with Hardy-Weinberg expectations was evaluated by

Send correspondence to Kátia Kvitko. UFRGS, Instituto de Biociências, Departamento de Genética, Caixa Postal 15053, 91501-970 Porto Alegre, RS, Brazil. E-mail: katia.kvitko@ ufrgs.br. the $\chi^{2}$ test (Roff and Bentzen, 1989) and Fisher's exact test. Comparisons of allelic frequencies were performed using the PEPI software program.

Allele and genotype frequencies are shown in Tables 1 and 2. The two samples were in Hardy-Weinberg equilibrium $(p=0,828$, Euro-Brazilians; $p=0,995$, Afro-Brazilians). The Euro-Brazilian allele prevalence was quite similar to those previously detected in a healthy Norwegian population (Kristensen et al., 1998), in a study of Belgians (Pottelberg et al., 2003), and in a British population (Baxter et al., 2001). However, it differed from those found in an Euro-American sample $\left(\mathrm{p}<10^{-3}\right)$ (Siegelman-Danieli and Buetow, 1999), in Japanese women $\left(\mathrm{p}<10^{-3}\right)$ (Miyoshi et al., 2000), in Russians $\left(\mathrm{p}<10^{-4}\right)$ (Suspitsen et al., 2002), in a British population ( $\mathrm{p}=0,006)$ (Healey et al., (2000) and in a Latin-American sample $(\mathrm{p}=0,0029)$ (Probst-Hensch et al., 1999). In addition to the five common alleles with seven (A5), eight (A4), nine (A3), eleven (A2) and twelve (A1) TTTA-repeats, we observed in one European-derived individual a rare allele with 13 repeats classified as $A 1 V$. The allele frequencies of the TTTA repeat differed statistically between Euro- and Afro-Brazilians, due to $A 2$ and $A 5$ allele distributions in these populations $\left(\mathrm{p}<10^{-3}\right.$ for both alleles). Two previously studied Afro-derived populations also showed allelic differences when compared to European-derived populations (Probst-Hensch et al., 1999; Gu et al., 2001). The allelic frequencies reported by ProbstHensch et al. (1999) in an Afro-American sample from California (USA) were similar to the frequencies detected in the present study. 
Table 1 - CYP19 allele distribution in Afro- and Euro-Brazilians ${ }^{1}$.

\begin{tabular}{lcc}
\hline Alleles & Afro-Brazilians & Euro-Brazilians \\
\hline$A 1 V$ & - & 0.003 \\
$A 1$ & 0.04 & 0.021 \\
$A 2$ & 0.09 & 0.284 \\
$A 3$ & 0.01 & 0.014 \\
$A 4$ & 0.06 & 0.092 \\
$A 5$ & 0.80 & 0.586 \\
\hline
\end{tabular}

${ }^{1} \mathrm{p}<10^{-4}$.

Table 2 - CYP19 genotype distribution in Afro- and Euro-Brazilians ${ }^{1}$.

\begin{tabular}{lcc}
\hline Genotype & Afro-Brazilians & Euro-Brazilians \\
\hline A1V-2 & 0 & 1 \\
A1-A1 & 0 & 0 \\
A1-A2 & 0 & 0 \\
A1-A3 & 0 & 0 \\
A1-A4 & 1 & 1 \\
A1-A5 & 9 & 5 \\
A2-A2 & 1 & 17 \\
A2-A3 & 0 & 1 \\
A2-A4 & 0 & 11 \\
A2-A5 & 21 & 36 \\
A3-A3 & 0 & 0 \\
A3-A4 & 1 & 1 \\
A3-A5 & 1 & 2 \\
A4-A4 & 0 & 1 \\
A4-A5 & 13 & 12 \\
A5-A5 & 77 & 58 \\
Total & 124 & 146 \\
\hline
\end{tabular}

${ }^{1} \mathrm{p}<10^{-3}$.

Previous studies had shown that CYP19 might be involved in breast cancer susceptibility (Kristensen et al., 1998; 2000; Siegelmann-Danieli and Buetow, 1999; Miyoshi et al., 2000), probably due to its role in the conversion of C19 steroids into estrogens. Population differences in the frequency of the CYP19 polymorphism as we disclosed here between Afro- and Euro-derived Brazilian populations are crucial in the interpretation of these association studies.

\section{Acknowledgments}

The authors thank Dr. Francisco M. Salzano for the critical reading of the manuscript. This work was supported by Programa de Apoio a Núcleos de Excelência (PROEX); Financiadora de Estudos e Projetos (FINEP); Conselho Nacional de Desenvolvimento Científico e Tecnológico (CNPq); Fundação de Amparo à Pesquisa do Estado do Rio Grande do Sul (FAPERGS)

\section{References}

Baxter SW, Choong DYH, Eccles, DM and Campbell IG (2001) Polymorphic variation in CYP19 and the risk of breast cancer. Carcinogenesis 22:347-349.

Gu CC, Mutch DG and Goodfellow PJ (2001) Association of the aromatase gene (CYP19) and endometrial cancer - Testing for Hardy-Weinberg disequilibrium in cancer patients. $50^{\text {th }}$ Annual Meeting ASHG, Philadelphia, USA. Am J Hum Genet 68:292.

Healey CS, Dunning AM, Durocher F, Teare D, Pharoah PDP, Luben RN, Easton DF and Ponder BAJ (2000) Polymorphisms in the human aromatase cytochrome P450 gene (CYP19) and breast cancer risk. Carcinogenesis 21:189-193.

Kristensen VN, Andersen TI, Lindblom A, Erikstein B, Magnus P and Brresen-Dale A (1998) A rare CYP19 (aromatase) variant may increase the risk of breast cancer. Pharmacogenetics 8:43-48.

Kristensen VN, Harada N, Yoshimura N, Haraldsen E, Lonning PE, Erikstein B, Karesen R, Kristensen T and Brresen-Dale A (2000) Genetic variants of CYP19 (aromatase) and breast cancer risk. Oncogene 19:1329-1333.

Miller SA, Dykes DD and Polesky HF (1988) A simple salting out procedure for extraction DNA from human nucleated cells. Nucl Acids Res 16: 215.

Miyoshi Y, Iwao K, Ikeda N, Egawa, C and Noguchi, S (2000) Breast cancer risk associated with polymorphism in CYP19 in Japanese women. Int J Cancer 89:325-328.

Probst-Hensch NM, Ingles SA, Diep AT, Haile RW, Stanczyk FZ, Kolonel LN and Henderson BE (1999) Aromatase and breast cancer susceptibility. Endocr Relat Cancer 6:165173.

Pottelbergh IV, Goemaere S and Kaufman JM. (2003) Bioavailable estradiol and na aromatase gene polymorphism are determinants of bone mineral density changes in men over 70 years of age. J Clin Endocrinol Metab 88:3075-3081.

Roff DA and Bentzen P (1989) The statistical analysis of mithocondrial DNA polymorphisms: $\chi^{2}$ and the problem of small samples. Mol Biol Evol 16:539-545.

Siegelmann-Danieli N and Buetow KH (1999) Constitutional genetic variation at the human aromatase gene (CYP19) and breast cancer risk. Brit J Cancer 79:456-463.

Suspitsen EN, Grigoriev MY, Togo AV, Kuligina ES, Belogubova, KM, Pozharisski KM, Chagunava OL, Sokolov EP, Theillet C, Berstein LM, Hanson KP and Imyanitov EN (2002) Distint prevalence of the CYP19 $\Delta 3$ (TTTA) 7 allele in premenopausal versus postmenopausal breast cancer patients, but not in control individuals. Eur J Cancer 38:19111916.

Associate Editor: Angela M. Vianna-Morgante 